\title{
Relationship between Human Resource Management Practices and Employee's Turnover Intention: An Empirical Study
}

\author{
Er Xin Peng ${ }^{*}$, Azlineer Sarip, Lily Suriani Mohd Arif, Zulkifli Khair \\ School of Human Resource Development and Psychology, Faculty of Social Sciences and Humanities, Universiti Teknologi Malaysia, 81310 UTM Johor \\ Bahru, Johor, Malaysia \\ *Corresponding author: xper2@live.utm.my
}

Article history: Received: 28 June 2021 Received in revised form: 11 July 2021 Accepted: 25 July 2021 Published online: 05 August 2021

\begin{abstract}
The objective of this study was to identify the relationship between Human Resource Management (HRM) practices and employees' turnover intention. This study employed a quantitative research approach by conducting a survey to collect data. By using convenience sampling, 70 permanent employees from the organization were sampled for the study. Employing SPSS version 18.0, descriptive statistical analysis revealed that level of HRM practices was moderate while turnover intention of respondents was at low level. Meanwhile, Spearman's rank correlation coefficient analysis showed that HRM practices were significantly negative correlated with turnover intention. In conclusion, these findings can be used by the management board of the organization to understand their employees' turnover intention and further improve HRM practices.
\end{abstract}

Keywords: Human resource management practices, turnover intention, hospitality industry, performance appraisal and reward

\begin{abstract}
Abstrak
Objektif kajian ini adalah untuk mengenal pasti hubungan antara amalan Pengurusan Sumber Manusia (HRM) dan niat pusing ganti pekerja. Kajian ini menggunakan pendekatan penyelidikan kuantitatif dengan mengedarkan soal selidik untuk mengumpulkan data. Dengan menggunakan pensampelan mudah, 70 orang pekerja tetap dijadikan sampel untuk kajian ini. Dengan menggunakan SPSS versi 18.0, analisis statistik deskriptif menunjukkan bahawa tahap amalan HRM adalah sederhana sementara niat pusing ganti pekerja berada pada tahap rendah. Sementara itu, analisis pekali korelasi Spearman menunjukkan bahawa amalan HRM mempunyai hubungan yang signifikan berkorelasi negatif dengan niat pusing ganti. Kesimpulannya, hasil kajian ini dapat digunakan oleh lembaga pengurusan organisasi untuk memahami niat pusing ganti pekerja mereka dan meningkatkan lagi amalan HRM.
\end{abstract}

Kata kunci: Pengurusan sumber manusia, niat pusing ganti pekerja, industri hospitaliti, penilaian prestasi dan ganjaran

(C) 2021 Penerbit UTM Press. All rights reserved

\subsection{INTRODUCTION}

Hospitality industry can be categorized as one of the rapid worldwide rising industries in many countries including Malaysia. It contributes more than one third income to the service sector and significantly improves the economic development in certain countries (AlBattat \& Som, 2013). Practically, the success of a hotel is strongly depending on their human resources who have direct contact with the customers. Hence, employees play a major role of the service and can significantly play a part in protecting the organizational image. Hotels may not operate smoothly without its employees (Holston-Okae \& Mushi, 2018). However, the huge number of employee turnover rates is the most challenging problem for the hospitality industry in order to provide excellent services and consequently retain its customers. Altarawmneh and Al-Kilani (2010) stated that the tourism and hospitality industry faces a HR crisis nowadays where employees' turnover rate is relatively greater than other industries such as banking and finance, and healthcare industry.

A small number of turnover is unavoidable and perceived as a benefit to the company. New members may inject fresh blood into the company by giving creative and innovative ideas, introducing new products and improving organization efficiency (Ampomah \& Cudjor, 2015). Despite the fact that employee turnover has positive effects on the organization, it also has negative impacts that should not be ignored. Based on Akinyomi (2016), high percentages of turnover rate bring a lot of negative consequences to organization such as losing of talents, and increasing recruitment and training cost. Bryant and Allen (2013) mentioned that an organization spends between 30\% to $50 \%$ of annual wage for entry-level workers, $150 \%$ of the yearly wages for middle-level workers and as high as $400 \%$ of the wage annually to substitute the workers especially for higher management level workers.

Iqbal (2010) claimed that the employee's turnover rate was affected by their intention to quit from the company. Hence, to minimize the actual turnover rate in the hotel, the hotel management needs to eliminate employees' intention to leave. According to Zhang (2016), there are three influencing factors of employee turnover intention which were individual issues, organization and work issues, and social 
and economic issues. Individual issues like gender, age, marriage status and education background are claimed to affect individual turnover intention indirectly. Organization and work issues which mainly include salary, promotion, employee involvement and enterprise culture also will affect employees' turnover intention. Moreover, labour market conditions, job opportunities, housing and living costs were classified as social and economic issues that may also have an effect on employee's turnover intention.

Review of literature revealed that employee turnover rates are greatly affected by the dissatisfaction of employees toward the overall HRM practices implemented in the organization (Albattat \& Som, 2013; Long \& Perumal, 2014; Sinniah \& Kamal, 2017). This factor was categorized under organization and work issues. Ruzuan (2019) defined that HRM practices as an approach conducted by the management of a company to manage their employees. If HRM practices are implemented poorly and ineffectively, employees would believe that they are not being appreciated by their employer. Hence, they will become less motivated and tend to have the intention to leave the company (Sinniah \& Kamal, 2017). There are many variables which are related with HRM practices such as recruitment and selection, performance appraisal, training and development, rewards, working conditions and career growth opportunities in an organization. Nivethitha, Dyaram and Kamalanabhan (2014) found that these variables positively or negatively correlate with turnover intention. In summary, the management needs to examine the correlation between HRM practices and employees' turnover intention at their hotel to identify whether the implementation of certain HRM practices is able to retain their high-skilled talents.

\subsection{LITERATURE REVIEW}

HRM practices perceive as particular practices, formal policies and philosophies that have been planned to attract, encourage, develop and retain staff to maintain the efficient operational and existence of the company (Tan \& Nasurdin, 2011). According to Tiwari and Saxena (2012), HRM practices are referred to organizational actions that focus on handling a group of manpower and confirming all the resources are employed towards the accomplishment of company targets. Even HRM practices do not affect organization's performances directly, but effective HRM practices can improve employee's skills, attitudes, and knowledge. Consequently, this can lead to the increase of organization's performance indirectly (Othman, Ahmad \& Hamzah, 2010).

Shaukat, Ashraf and Ghafoor (2015) explained that HRM practices are the actual HR processes, programs, and techniques that are implemented in the company or business unit. They supposed that HRM practices can result in higher levels of job satisfaction which ultimately decreases organizational turnover rate. Kee (2016) also argued that the main goal of HRM practices is to retain and motivate employees. If employees are pleased with specific HRM practices, they will be less likely to have the intention to quit their organization.

There are several HRM practices often conducted in organization. The researcher adapted four types of HRM practices in this study which were performance appraisal, reward, working condition, and training and development. Performance appraisal is a necessary process of personnel management that is designed to determine a worker's job performance level, identify employee strengths and weaknesses, identify training needs, and encourage supervisors to understand their subordinates (Onyije, 2015). Reward is the benefits that employees receive from a company for their effort and service. It includes financial and non-financial compensation. The main function of a reward system is to attract the suitable candidates to the job, compensate and retain excellent employees, and encourage them to perform at their best (Lim \& Ling, 2012).

Working condition is referred to work circumstances and all existing environments that may influence the employees in the working place. It consists of physical aspects, working hours, legalisation and responsibilities (Chong et al., 2015). Noe et al. (2018) explained that training and development is a planned strategy to allow workers to get job-related knowledge, skills, and attitudes. Meanwhile, Gadi \& Kee (2018) explained that the focus of training was to gain abilities, information, and behaviours expected to conduct current tasks while development programs are not work-related and principally focus on future job demands.

Sinniah and Kamil (2017) explained turnover intention as conscious willingness to quit the company, which consists of a thought or idea of existing, the action of finding a new occupation, and a decision to leave the job. Turnover can be categorized into three types which were desirable turnover, undesirable turnover and unavoidable turnover. Desirable turnover is applied to those employees who are not capable of carrying their job. It is different with undesirable turnover which occurs when an organization loses a skilled, talented and competent employee. On the other hand, unavoidable turnover may occur due to sickness, family matter or retirement (Ngo-Henha, 2017).

Employee's turnover intention would lead to voluntary turnover where it normally involves competent workers quitting their position. In fact, personal issues and employee attitudes, performance appraisal and feedback, lack of recognition, lack of personal and professional advancement, and communication barriers in the organization can increase the employee's turnover intention (Iqbal, 2010). They will be more likely to choose another job that they are most satisfied with (Saeed et al., 2014). Voluntary turnover can be very costly for a company because it involves the expenses related to recruiting and hiring a new worker. Indeed, an employee's intention to exit can be avoided and prevented by actions of the company like providing equal career opportunity and raising employees' salary (Iqbal, 2010).

Numerous researches related to establish the correlation between HRM practices and employees' turnover intention have been carried out in the past decades. Mat (2015) carried out a research to identify the link between human resource practices and turnover intention at a local university. Results confirmed that there was a significant negative correlation between HRM practices and employees' turnover intention. Moreover, the findings also indicated that compensation and benefits was the most crucial variable needed to be improved in order to minimize the employees' turnover intention in the organization.

Ruzuan (2019) also conducted research to study the relationship of three human resource practices (training and development, reward and benefits, and performance appraisal) toward turnover in an organization. The results showed that HRM practices were negatively linked with employees' turnover intention. Even the results showed that the relationship between HRM practices and turnover was weak but it still brought some effects toward turnover rate in that company. Researchers also found that all three HRM practices had a correlation with turnover rate in the company. However, training and development, and reward and benefits had a stronger relationship with turnover compared with performance appraisal.

Sinniah \& Kamil (2017) found that there was a significant correlation between performance appraisals and intention to quit. Performance appraisals became the core indicator for workers to $\mathrm{k}$ for their career for long term. This was because performance appraisals 
influenced compensation, promotion, transfer of knowledge. It helped employees to plan their future development in the certain company. Moreover, a clear performance appraisal helped employees to identify and overcome their weaknesses. When they were able to overcome their problems or weaknesses at the workplace, they were happier to work and had a low turnover intention (Ruzuan, 2019).

In addition, Santhanam et al. (2017) conducted a study and found that there was a significant negative correlation between reward system and turnover intention among employees in the hotel industry. According to Cheng and Lai (2017), if employees perceive a higher degree of justice, controllability, expectation, and communication in the reward system, their job satisfaction will be higher and demonstrate lower level of turnover intention.

Hee et al. (2018) defined working conditions as a key component that influences employee's job satisfaction as well as organizational productivity and loyalty. It can increase employee retention if the company is able to provide flexible working hours and helps employees to promote work-life balance. Furthermore, perceived emotional support from colleagues and supervisors is also linked with employees' turnover intention. A positive work environment can also reduce employees' stress, increase job satisfaction as well as decrease their turnover intention (Holston-Okae and Mushi, 2018).

On the other hand, productivity and employees' satisfaction will increase when the training programs are effective. As a consequence, it will also lead to the company's job turnover decrease. When employer and employees' training needs are achieved, the more likely employees stay in their organizations. Moreover, job satisfaction and organizational commitment can be affected by training and development. At the end of the day, staff retention can also be affected indirectly (Sinniah \& Kamil, 2017).

\subsection{METHODOLOGY}

Research design is a blueprint created to control variables and answers to the research questions - it will guide the research activity and ensure the data collection and analysis process run efficiently (Dulock, 1993). Descriptive study has been employed by researchers to describe characteristics of a sample and answer the first and second research objectives by examining the implementation level of HRM practices and the level of employee's turnover intention. In addition, correlational study attempted to answer the third research objective by identifying the relationship between HRM practices and turnover intention among employees. Next, researchers used a quantitative research approach in this study where a set of questionnaire as an instrument in this study was distributed to the sample of the targeted population. The questions in the questionnaires were adopted from Juneau, Anchorage and Kodiak (2008), Syed, Daniel and Gloria (2008) and Waleed (2011). There were 70 questionnaires distributed to the respondents. A cross-sectional study was used to distribute questionnaires which meant data would be only collected at one point in time.

Population is a collection or summation of all the subjects, objects, or members that conform to a set of qualifications (Mbokane, 2009). Meanwhile, a sample was a portion of the population which is selected and becomes the main focus of research enquiry to represent the study population (Mbokane, 2009). In this study, the population included all the permanent employees who worked at The Hotel. The population consisted of both the operation and management level of employees at that hotel. In all, there were about 85 permanent employees who acted as the population of this study. To determine the sample size, researchers used the Krejcie and Morgan sampling table (1970). There were 70 permanent employees who were chosen as the samples by using a convenience sampling technique. According to Eid (2012), convenience sampling is suitable to apply in the hospitality industry because many departments of hotels operate on a shift basis. Thus, it was more convenient for researchers because the research only involved those respondents who were at work during the data collection process.

A sum of 70 sets of questionnaires were distributed to the respondents and collected back from them after the questionnaires were answered completely. All of the distributed questionnaires (70 sets) were valid filled and returned. The questionnaire consisted of three parts, which were Part A (demographic data), Part B (HRM practices), and Part C (turnover intention). Items in Part A were measured using multiple choices while items in Part B and C were measured using Five-Point Likert Scale (1 represented strongly disagree and 5 represented strongly agree).

Descriptive statistical analysis was used to calculate the frequency, mean score, and percentage whereas inferential statistical analysis was utilized to analyze the correlation between the variables. The data collected were analyzed through Statistical Package for the Social Sciences version 18 (SPSS 18.0). The method of mean score was used to identify employee's levels of HRM practices and turnover intention. According to Kumar (2014), a five-point Likert scale is needed to divide into three levels which are low, moderate, and high in order to determine the level of the mean score. On the other hand, Spearman's rank correlation coefficient was used to examine the relationship between HRM practices and turnover intention among the employees.

\subsection{RESULTS}

Table 1 exhibited that the majority of the respondents were male employees (58.6.8\%) while female employees were $41.4 \%$. Most of the respondents were below 26 years old (38.6\%). On the respondents' race distribution, most of the respondents were Malay (77.1\%). Moreover, the majority of respondents were in the single status $(57.1 \%)$ while another $42.9 \%$ of the respondents were married. In terms of highest education completed, largest of the respondents were Diploma holders (41.4\%). Meanwhile, the majority of the respondents' basic salary ranged from RM1501 to RM2500 (34.3\%). 
Table 1 Demographic characteristics of the respondents ( $\mathrm{n}=70$ respondents)

\begin{tabular}{|c|c|c|}
\hline Variables & Frequency $(f)$ & $\begin{array}{c}\text { Percentage } \\
(\%)\end{array}$ \\
\hline \multicolumn{3}{|l|}{ Gender } \\
\hline Female & 29 & 41.4 \\
\hline Male & 41 & 58.6 \\
\hline \multicolumn{3}{|l|}{ Age } \\
\hline Below 26 & 27 & 38.6 \\
\hline $26-35$ & 24 & 34.3 \\
\hline $36-45$ & 9 & 12.9 \\
\hline $46-55$ & 8 & 11.4 \\
\hline More than 55 & 2 & 2.9 \\
\hline \multicolumn{3}{|l|}{ Race } \\
\hline Malay & 54 & 77.1 \\
\hline Chinese & 7 & 10.0 \\
\hline Indian & 5 & 7.1 \\
\hline Others & 4 & 5.7 \\
\hline \multicolumn{3}{|l|}{ Marital Status } \\
\hline Single & 40 & 57.1 \\
\hline Married & 30 & 42.9 \\
\hline Variables & Frequency $(f)$ & $\begin{array}{c}\text { Percentage } \\
(\%)\end{array}$ \\
\hline \multicolumn{3}{|l|}{ Highest Education } \\
\hline \multicolumn{3}{|l|}{ Completed } \\
\hline Diploma & 29 & 41.4 \\
\hline Degree & 18 & 25.7 \\
\hline Master & 4 & 5.7 \\
\hline Phd & 1 & 1.4 \\
\hline Others & 18 & 25.7 \\
\hline \multicolumn{3}{|l|}{ Basic salary } \\
\hline Below RM1500 & 22 & 31.4 \\
\hline RM1501-RM2500 & 24 & 34.3 \\
\hline RM2501-RM3500 & 13 & 18.6 \\
\hline RM3501-RM4500 & 7 & 10.0 \\
\hline RM4501-RM5500 & 3 & 4.3 \\
\hline Above RM 5500 & 1 & 1.4 \\
\hline Total & 70 & 100 \\
\hline
\end{tabular}

Table 2 showed the overall mean score of HRM practices by using the descriptive statistic method. The finding indicated that the level of HRM practices was at moderate level. The overall mean score was 3.62 and standard deviation was 0.2894. Data analysis for the level of HRM practices was based on the four dimensions which were performance appraisal (mean score $=3.67, \mathrm{SD}=0.4423$ ), reward (mean score $=3.69, \mathrm{SD}=0.5835)$, working condition (mean score $=3.65, \mathrm{SD}=0.4745)$, and training and development $($ mean score $=3.49, \mathrm{SD}=$ $0.3952)$.

Table 2 Level of HRM Practices

\begin{tabular}{lccc}
\hline \multicolumn{1}{c}{ Dimensions } & Mean & $\begin{array}{c}\text { Standard deviation } \\
(\text { SD })\end{array}$ & Level \\
\hline Performance Appraisal & 3.68 & 0.4423 & High \\
Reward & 3.69 & 0.5835 & High \\
Working Condition & 3.65 & 0.4745 & Moderate \\
Training and Development & 3.49 & 0.3952 & Moderate \\
$\quad$ Overall & $\mathbf{3 . 6 2}$ & $\mathbf{0 . 2 8 9 4}$ & Moderate \\
\hline \multicolumn{2}{c}{ Mean value $($ Low $=1.00-2.33 ;$ Moderate $=2.34-3.67 ;$ High $=3.68-5.00)$} &
\end{tabular}

Table 3 illustrated the overall mean score of turnover intention among permanent employees at The Hotel by using the descriptive statistic method. The findings showed that employees' turnover intention was found to be at a low level (mean score $=$ 2.21, $\mathrm{SD}=0.7995$ ).

Table 3 Level of Employees' Turnover Intention

\begin{tabular}{lccc}
\hline Dimensions & Mean & $\begin{array}{c}\text { Standard Deviation } \\
\text { (SD) }\end{array}$ & Level \\
\hline Employees' Turnover Intention & 2.21 & 0.7995 & Low \\
\hline Mean value (Low $=1.00-2.33$; Moderate $=2.34-3.67 ;$ High $=3.68-5.00)$ &
\end{tabular}


Table 4 presented the correlations analysis between HRM practices and turnover intention among permanent employees. The finding indicated that there was a significant negative weak correlation between HRM practices and employees' turnover intention $(\mathrm{r}=-$ $0.277 *)$.

Table 4 Correlations between HRM practices and Employees Turnover Intention

\begin{tabular}{ccc}
\hline Variables & $\boldsymbol{r}$ & $\boldsymbol{P}$ \\
\hline HRM Practices and Turnover Intention & $-0.277^{*}$ & 0.020 \\
\hline Correlation is significant at the 0.05 level $(2$-tailed); $\mathrm{N}=70$ &
\end{tabular}

\subsection{DISCUSSION AND RECOMMENDATION}

The findings of the study revealed a moderate level of HRM practices (mean score $=3.62, \mathrm{SD}=0.2894$ ), similar with the results found by Sinniah and Kamil (2017), and Long and Perumal (2014). Moderate level of HRM practices in this study was due to the fact that respondents were satisfied with certain aspects like performance appraisal (mean score $=3.67, \mathrm{SD}=0.4423$ ) and reward system (mean score $=3.69, \mathrm{SD}=0.5835$ ), however they were less satisfied with other aspects like working condition (mean $\mathrm{score}=3.65, \mathrm{SD}=0.4745)$, and training and development (mean score $=3.49, \mathrm{SD}=0.3952$ ). Respondents were less satisfied with working conditions because they did not have flexibility to arrange their work schedule to fit with their lifestyle and moderately enjoyed working with their colleagues. While those respondents were not very satisfied with the training and development because they were not attending training programs every year. Moreover, not all the employees but only certain representatives had the chance to attend the training programs. Besides, employees also thought that formal training programs that they attended did not help them to get job promotion in the hotel. Therefore, these led to the moderate implementation level of working condition, and training and development. Even the overall mean scores of HRM practice was categorized in middle level, but it was near to high level. This meant that the organization had put an effort in order to provide better HRM practices. This was supported by Santhanam et al. (2017), nowadays organizations play more concern in providing good HRM practices because excellent HRM practices will increase employee's job satisfaction and their productivity, minimize employee turnover, and lead to the overall improvement in organizational performances.

The findings of the study also revealed that employees in this study had a low level of turnover intention (mean score $=2.21$, $\mathrm{SD}=0.7995$ ). One of the reasons that influenced the level of employees' turnover intention was employees' demography background such as gender. Males had lower turnover intentions than females (Emiroglu, Akova \& Tanriverdi, 2015; Lee, 2012). This was due to the family-related reasons and limited career development opportunities faced by female employees. In this study, the number of male employees (41 persons) was higher than female employees (29 persons). Hence, this became one of the reasons that led to the lower level of turnover intention among employees. Other than demographic background, employee turnover intention was also influenced by hotel categories. Based on the findings of Duraisamy (2018), employees who worked in five or four stars hotels were rarely to quit their jobs rather than the employees who worked in one, two, or three stars hotels. This hotel is a four stars business hotel in Malaysia. As compared to other low star hotels, it is able to provide better welfare for their employees such as well working conditions, more career opportunities, and higher salary. Thus, this might have reduced turnover intention among employees of The Hotel. Another reason that led to the low level of turnover intention was the type of employment. The present study only involved permanent employees. A study conducted by Qian et al. (2017) found that temporary employees had higher turnover intentions than permanent employees. Usually, temporary jobs are low wage and welfare, receive lower levels of human resources investments and tend to be highly stressful. Hence, this study only involved permanent employees and might lead to the lower level of employee's turnover intention.

Finally, the overall findings show that HRM practices had significant relationship with turnover intention among employees. These findings were in line with previous researches, which also noted that there was a significant negative correlation between HRM practices and employee's turnover intention (Ruzuan, 2019; Santhanam et al., 2017; Mat, 2015). Santhanam et al., (2017) explained that good and perfect HRM practices in a hotel can reduce employees' intention to leave. Another research that was conducted by Mat (2015) with the aim to investigate the link between HRM practices and employees' turnover intention at a local university also obtained a result that is similar with current research finding. The weak but significant relation between dependent variable and independent variable was similar with the result found by Ruzuan (2019). Even the finding showed that the relationship between HRM practices and turnover is weak but it still has brought some effects toward turnover rate in the hotel. These findings proved that the implementation of HRM practices would negatively influence employees' turnover intention. In other words, when the level of HRM practices is high, the level of employees' turnover intention will be low. If a hotel is able to implement good HRM practices and improves welfare for their employees, then the employees would be more likely to stay.

\subsection{CONCLUSION}

The purpose of this research was to identify the level of HRM practices and employees' turnover intention as well as to examine the relationship between HRM practices and employees' turnover intention. Results of this study discovered that HRM practice was in moderate level while their turnover intention level was reported as low. In addition, the study also identified that there was a relatively weak but significant negative relationship between HRM practices and turnover intention among employees. Therefore, it is found that continuous implementation of HRM practices can lower employees' turnover intention. 
In a nutshell, this study highlighted the relationship between HRM practices and employees' turnover intention in four dimensions (performances appraisal, reward, working condition, and training and development). More studies need to be carried out in order to explore more relevant HRM practices that may affect the relationship and provide a more comprehensive understanding about employees' turnover intention in Malaysia's hotel context.

\section{References}

Akinyomi, O. J. (2016). Labour turnover: Causes, consequences and prevention. Fountain University Journal of Management and Social Sciences, 5(1), 105-112.

AlBattat, A. R. S., \& Som, A. P. M. (2013). Job satisfaction and turnover crises in Malaysia's hospitality industry. In International Conference on Tourism Development, 260-266.

Altarawmneh, I., \& Al-Kilani, M. H. (2010). Human resource management and turnover intentions in the Jordanian hotel sector. Research and Practice in Human Resource Management, 18(1), 46-59.

Ampomah, P., \& Cudjor, S. K. (2015). The effect of employee turnover on organizations (case study of Electricity Company of Ghana, Cape Coast). Asian Journal of Social Sciences and Management studies, 2(1), 21-24.

Bryant, P. C., \& Allen, D. G. (2013). Compensation, benefits and employee turnover HR strategies for retaining top talent. Compensation and Benefits Review, 45(3), 171-175. doi:10.1177/088636871349434

Cheng, Y. \& Lai, H, H. (2017). The Effects of Training and Reward Systems on Employee Willingness to Stay - A Case Study of an International Tourist Hotel in Taipei. International Journal of Research in Tourism and Hospitality (IJRTH), 3(1), 21-33.

Chong, P. W., Khor, W. H., Lee, J. L., Ooi, S. Y., \& Tan, Y. K. (2013). The impact of HRM practices on employee turnover intention in UTAR (Degree Thesis). Universiti Tunku Abdul Rahman.

Dulock, H.L. (1993). Research design: descriptive research. Journal of Pediatric Oncology Nursing, 10(4), $154-157$.

Duraisamy, P. (2018). Human resource management and turnover intentions in the hotel industry. International Journal of Business and Administration Research Review, 1(22), 92-99.

Eid, R. (2012). Successful customer relationship management programs and technologies: Issues and trends. Hershey: IGI Global.

Emiroğlu, B. D., Akova, O., \& Tanriverdi, H. (2015). The relationship between turnover intention and demographic factors in hotel businesses: A study at five star hotels in Istanbul. Procedia-Social and Behavioral Sciences, 207, 385-397.

Gadi, P. D., \& Kee, D. M. H. (2018). Human resource management practices and turnover intention: the mediating role of perceived organization support in tertiary institutions in Nigeria. International Journal of Engineering \& Technology, 7(3), 715-722.

Hee, O. C., Lien, C. M., Liang, S. J., Ali, A. S., Manap, N. S., Lailee, S. N. (2018). Human resource management practices and employee's turnover intention in the manufacturing industry in Malaysia. International Journal of Human Resource Studies, 8(2), $216-226$

Holston-Okae, B. L., \& Mushi, R. J. (2018). Employee turnover in the hospitality industry using Herzberg's Two-Factor Motivation-Hygiene Theory. International Journal of Academic Research in Business and Social Sciences, 8(1), 218-248.

Juneau, Anchorage, and Kodiak. (2008). Employee Satisfaction Survey Report. DOT\&PF Employee Satisfaction Survey Report. 6. Retrieved on March 21, 2019, from https://www.slideshare.net/SunilJoshi15/dot-reporttostaff

Iqbal, A. (2010). Employee turnover: Causes, consequences and retention strategies in the Saudi organizations. The Business Review, Cambridge, 16(2), 275-281.

Kee, S. Y. (2016). Hubungan di antara amalan pengurusan sumber manusia dan kehendak untuk kekal di Syarikat Pengeluaran Teluk Melaka (Degree Thesis), Universiti Teknologi Malaysia.

Krejcie, R. V., \& Morgan, D. W. (1970). Determining sample size for research activities. Educational and Psychological Measurement, 30(3), 607-610.

Kumar, R. (2014). Research methodology: A step-by-step guide for beginners. London: Sage Publications Ltd.

Lee, T. H. (2012). Gender differences in voluntary turnover: Still a paradox?. International Business Research, 5(10), 19-28.

Lim, L. J., \& Ling, F. Y. (2012). Human resource practices of contractors that lead to job satisfaction of professional staff. Engineering, Construction and Architectural Management, 19(1), 101-118.

Long, C. S., \& Perumal, P. (2014). Examining the impact of human resource management practices on employees turnover intention. International Journal of Business \& Society, 15(1), 111-126.

Mat, N. H. (2015). The relationship between human resource practices and turnover intension (Master Thesis), Universiti Utara Malaysia.

Mbokane, A. (2009). The utilisation of contraceptives by women who requested termination of pregnancy services in the Gert Sibande District (Mpumalanga)(Master Thesis), University of South Africa.

Ngo-Henha, P. E. (2017). Review of existing turnover intention theories. International Journal of Economics and Management Engineering, 11(11), $2760-2767$.

Nivethitha, S., Dyaram, L., \& Kamalanabhan, T. J. (2014). Human resource practices and employee turnover intentions in hospitality industry. Global Journal of Management and Business Research, 14(1), 35-42.

Noe, R. A., Hollenbeck, J. R., Gerhart, B., Wright, P. M. (2018). Fundamentals of human resource management 7th Edition. Maidenhead: McGraw-Hill Higher Education.

Onyije, O. C. (2015). Effect of performance appraisal on employee productivity in a Nigerian University. Journal of Economics and Business Research, 21(2), 65-81

Othman, N., Ahmad, Z., \& Hamzah, M. I. M. (2010). Pengaruh amalan pengurusan sumber manusia (PSM) terhadap hasil PSM di IPTS bukan bertaraf universiti. Jurnal Pengurusan, 31, 43-53.

Qian, X., Li, Q., Wu, Q., \& Wu, Y. (2017, July). The impact of temporary employment on employees' organizational citizenship behavior and turnover intention: the moderating effect of organizational identification. In International Conference on Management Science and Engineering Management, $791-803$.

Ruzuan, N. S. (2019). Hubungan antara amalan pengurusan sumber manusia dan pusing ganti kerja dalam organisasi (Degree Thesis), Universiti Teknologi Malaysia.

Saeed, I., Waseem, M., Sikander, S., \& Rizwan, M. (2014). The relationship of turnover intention with job satisfaction, job performance, leader member exchange, emotional intelligence and organizational commitment. International Journal of Learning and Development, 4(2), 242-256.

Santhanam, N., Kamalanabhan, T. J., Dyaram, L., \& Ziegler, H. (2017). Impact of human resource management practices on employee turnover intentions. Journal of Indian Business Research, 9(3), 212-228.

Shaukat, H., Ashraf, N., \& Ghafoor, S. (2015). Impact of human resource management practices on employees performance. Middle-East Journal of Scientific Research, 23(2), 329-338.

Sinniah, S., \& Kamil, N. M. (2017). The influence of human resource practices on turnover intention: The case of a telecommunication company in Malaysia. Malaysian, Malaysian Management Review, 52(1), 45-61.

Syed, A, Daniel, Z. D., \& Gloria L. G. E., (2008). Strategic HRM practices and Their Impact on Company Performance in Chinese Enterprises. Human Resources Management, 47(1), 15-32.

Tan, C. L., \& Nasurdin, A. M. (2011). Human resource management practices and organizational innovation: assessing the mediating role of knowledge management effectiveness. Electronic Journal of Knowledge Management, 9(2), 155-167.

Tiwari, P., \& Saxena, K. (2012). Human resource management practices: A comprehensive review. Pakistan Business Review, 9(2), 669-705.

Waleed, A. (2011). The Relationship Between Human Resource Practices and Employee Retention In Public Organization: An Exploratory Study Conducted In The United Arab Emirates. Unpublished Thesis, Edith Cowan University.

Zhang, Y. (2016). A review of employee turnover influence factor and countermeasure. Journal of Human Resource and Sustainability Studies, 4(02), 85-91. 